\title{
Collembolan communities as bioindicators of land use intensification
}

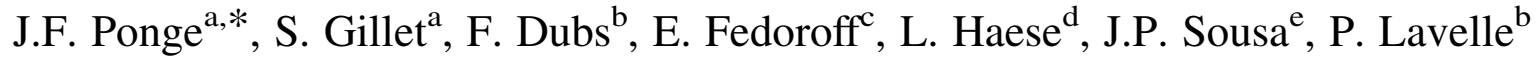 \\ ${ }^{a}$ Museum National d'Histoire Naturelle, CNRS UMR 8571, 4 avenue du Petit-Chateau, Brunoy 91800, France \\ ${ }^{\mathrm{b}}$ Institut de Recherche pour le Développement, UMR 137 BioSol, 32 rue Henri Varagnat, 93143 Bondy Cédex, France \\ ${ }^{c}$ Museum National d'Histoire Naturelle, Conservatoire Botanique National du Bassin Parisien, Maison du Parc, 58230 Saint-Brisson, France \\ ${ }^{\mathrm{d}}$ Autun-Morvan-Écologie, 19 rue de l'Arquebuse, BP 22, 71401 Autun Cédex, France \\ ${ }^{\mathrm{e}}$ Universidade de Coimbra, Instituto do Ambiente e Vida, Lg. Marquês de Pombal, 3004-517 Coimbra, Portugal
}

Received 8 August 2002; received in revised form 18 February 2003; accepted 25 February 2003

\begin{abstract}
Springtail communities (Hexapoda: Collembola) were sampled in the Morvan Nature Regional Park (Burgundy, France) in six land use units (LUUs) $1 \mathrm{~km}^{2}$ each, which had been selected in order to cover a range of increasing intensity of land use. Human influence increased from LUU 1 (old deciduous forest) to LUU 6 (agricultural land mainly devoted to cereal crops), passing by planted coniferous forests (LUU 2) and variegated landscapes made of cereal crops, pastures, hay meadows, conifer plantations and small relict deciduous groves in varying proportion (LUUs 3-5). Sixteen core samples were taken inside each LUU, at intersections of a regular grid. Species composition, species richness and total abundance of collembolan communities varied according to land use and landscape properties. Land use types affected these communities through changes in the degree of opening of woody landscape (woodland opposed to grassland) and changes in humus forms (measured by the Humus Index). A decrease in species richness and total abundance was observed from old deciduous forests to cereal crops. Although the regional species richness was not affected by the intensification gradient (40-50 species were recorded in every LUU), a marked decrease in local biodiversity was observed when the variety of land use types increased. In variegated landscapes the observed collapse in local species richness was not due to a different distribution of land use types, since it affected mainly woodland areas. Results indicated the detrimental influence of the rapid afforestation of previous agricultural land, which did not afford time for the development of better adapted soil animal communities.
\end{abstract}

(C) 2002 Elsevier Science Ltd. All rights reserved.

Keywords: Land use; Biodiversity; Humus Index

\section{Introduction}

Collembolan communities have been shown to vary in abundance and species composition according to changes in vegetation and soil conditions (Hågvar, 1982; Ponge, 1993; Chagnon et al., 2000). Soil acidity, mainly through associated changes in food and habitat, but also through chemical composition or osmolarity of the soil solution, may favor or disfavor some species (Hågvar and Abrahamsen, 1984; Vilkamaa and Huhta, 1986; Salmon and Ponge, 2001), and pH 5 has been noted as a landmark between two distinct types of communities (Ponge, 1993). The opposition between grassland and woodland can also be traced by the species composition of springtail populations (Gisin, 1943; Rusek, 1989; Ponge, 1993). As a whole, Collembola are

\footnotetext{
* Corresponding author. Tel.: + 33-1-6047-9213; fax: + 33-1-6046-5009.

E-mail address: jean-francois.ponge@wanadoo.fr (J.F. Ponge).
}

highly tolerant of a wide range of environmental conditions, including agricultural and industrial pollution, but species differ strongly in their sensitivity to environmental stress (Lebrun, 1976; Prasse, 1985; Sterzyńska, 1990). The parthenogenetic collembolan Folsomia candida is now currently used as a standard in the assessment of environmental risk (Riepert and Kula, 1996; Cortet et al., 1999; Crouau et al., 1999). In the search for indicators of environmental change, more especially those affecting biodiversity, abundant, diverse animal communities can be used to trace changes taking place at the landscape level, as this has been demonstrated in other arthropod groups (Duelli et al., 1990; Halme and Niemelä, 1993).

The present study was undertaken within the European Community project BioAssess. Here we present springtail results (Hexapoda: Collembola) from the French sites, which were located in the Morvan Regional Nature Park 
(Burgundy). This central region was selected for its high variety of land use types, ranging from large areas of old forests or cereal crops to variegated landscapes with intricate deciduous and coniferous woodlands, pastures, hay meadows and agricultural fields (Plaisance, 1986). We asked whether there was a response of collembolan communities to land use intensification and, if yes, whether this effect was just a replacement of species or affected biodiversity patterns.

\section{Material and methods}

\subsection{Study sites}

Sampling took place in the Morvan Regional Nature Park, which covers most of the northern part of the Morvan natural region (western Burgundy, Centre of France). The climate is continental, with an annual rainfall averaging $1000 \mathrm{~mm}$ and a mean temperature of $9{ }^{\circ} \mathrm{C}$. The parent rock is granite. The soil trophic level is poor, but despite moderate to strong acidity, the dominant humus form is mull (Perrier, 1997).

In the Morvan region, land use is shared between sylviculture $(45 \%)$ and agriculture $(55 \%)$. Forested areas are comprised of coniferous stands (silver fir, Douglas fir, Norway spruce) with an artificial intensive management system (45\%), and deciduous stands (beech, oak) with a semi-natural or a traditional management system $(55 \%)$. Agricultural areas are made up of grassland (80\%, among which $40 \%$ are permanent pastures and $40 \%$ are temporary hay meadows) and crops (20\%) with dominance of cereals (wheat, barley) and conifer trees (Norway spruce, Douglas fir). Agricultural management systems exhibit a wide range of disturbance intensity (use of mineral fertilizers and pesticides to organic manure only). Several socio-economical and political driving forces influenced dynamics and composition of the landscape during the last five decades (Plaisance, 1986). Many old deciduous forests have been transformed to coniferous plantations and more recently forested areas expanded by afforestation of previous agricultural land, using European subsidies.

Six land use units (LUUs), one square kilometer each, have been chosen on the basis of aerial photographs, taking into account the distribution of forested areas (coniferous, deciduous), meadows and agricultural crops. LLUs 1-6 depicted a gradient of increasing influence of human activities:

- LUU 1 is within an old (100-150 year) deciduous forest landscape managed by the French National Office of Forests (public sector). This forested area is made of acidophilic beechwoods (Fagus sylvatica L.), oakwoods (Quercus petraea (Mattus.) Liebl.) and mixed stands, with holly (Ilex aquifolium L.) in the understory. The management system is based on natural regeneration and selection by man. LUU 1 is made up of stands at different stages of forest development.

- LUU 2 is within a more recent (20-50 year) coniferous forest landscape managed by the French Forest National Office (public sector), mostly made of silver fir plantations (Abies alba Mill.). Previous land use was deciduous forest. Where soils were too wet for coniferous growth spontaneous vegetation was let to grow (willow, alder, birch). The management system of coniferous stands is intensive and based on artificial regeneration (clear-cut followed by plantation).

- LUU 3 is comprised of meadows within a forested landscape. Originally farmers cleared the native forest. Currently, by the way of national subsidies for afforestation of agricultural land, Douglas fir (Pseudotsuga menziesii (Mirb.) Franco) and Norway spruce (Picea abies (L.) Karst.) were planted 50 years ago on previous agricultural land purchased by private insurance companies. Remains of the old deciduous forest (now managed as beech and oak coppice) are also present, as well as a few cereal crops.

- LUU 4 is a mixed land use mosaic characterized by the presence of wet meadows. The agricultural system is based on organically manured meadows and intensive cereal crops (recently converted to organic farming). Some plots were afforested with Douglas fir and Norway spruce about 30 years ago.

- LUU 5 is a meadow landscape. The dominant agricultural system is based on organic farming. A few plantations of Douglas fir or Norway spruce (20-50 years old) are also present, as well as a few relict deciduous thickets pastured by livestock.

- LUU 6 is an agricultural landscape dominated by cereal crops. The agricultural system is intensive with a range of intensity levels depending on the farmer, but pesticides and mineral fertilizers are used currently. Some plots are prescribed fallow, some others have recently turned to short rotation conifer crops (Christmas trees). Recently abandoned land (scrub) is also present.

\subsection{Sampling procedure}

Using aerial photographs, a grid of 16 regularly spaced plots $(200 \mathrm{~m})$ was identified in each of the six LUUs, and their position in the field was found by their spatial coordinates, given by a calibrated GPS system. Each sampling plot was indicated by a central post. Litter and soil springtails were sampled by taking a core $(5 \mathrm{~cm}$ diameter, $10 \mathrm{~cm}$ depth) at a $3 \mathrm{~m}$ distance from the central post, in a northerly direction. Soil and litter were immediately sealed in a polythene bag then transported within 3 days to the laboratory. Sampling took place in June 2001. Extraction was performed within 10 days using the dry funnel method. Animals collected under the desiccating soil were preserved in $95 \%$ ethyl alcohol before being sorted under a dissecting microscope. Collembola were mounted in 
Table 1

Humus Index and morphological criteria used for the separation of humus forms according to Brêthes et al. (1995) and Ponge et al. (2000, 2002)

\begin{tabular}{llllll}
\hline Humus Index & Humus form & OL horizon & OM horizon & OF horizon & OH horizon \\
\hline 1 & Eumull & Absent & Absent & Absent & Absent \\
2 & Mesomull & Present & Absent & Absent & Absent \\
3 & Oligomull & Present & Absent & Present but $<1 \mathrm{~cm}$ & Absent \\
4 & Dysmull & Present & Absent & $1 \mathrm{~cm}$ or more & Absent \\
5 & Amphimull & Present & Absent & Present & Present \\
5 & Hemimoder & Present & Absent & Present & Absent \\
6 & Eumoder & Present & Absent & Present & Present but $<1$ cm \\
7 & Dysmoder & Present & Absent & Present & Compl \\
8 & Amphimoder & Present & Present & Absent & Compact more \\
9 & Mor & Present & Present & Absent & Absent \\
\hline
\end{tabular}

chloral-lactophenol ( $25 \mathrm{ml}$ lactic acid, $50 \mathrm{~g}$ chloral hydrate, $25 \mathrm{ml}$ phenol) and identified to species under a phase contrast microscope at $\times 400$ magnification. Identification was done using Gisin (1960), Zimdars and Dunger (1994), Jordana et al. (1997), Fjellberg (1998) and Bretfeld (1999).

Humus forms (Table 1) were identified in the vicinity of core samples, after visual inspection of trenched soil, using morphological criteria defined by Brêthes et al. (1995). Mor was separated from Dysmoder using Ponge et al. (2000). The Humus Index was measured at each sampling plot after scaling humus forms according to principles presented by Ponge et al. (2002).

Amphimoder was defined for the first time in order to classify humus forms presenting both features of mull (crumby A horizon) and mor (litter with an OM horizon, without any visible signs of animal activity). Agricultural Moder was also defined for the first time to classify an agricultural solum with a spongy structure made of small enchytraeid faeces (Didden, 1990; Topoliantz et al., 2000), and was given a Humus Index of 6 as for Eumoder. Other agricultural soils exhibited a crumby structure made of faeces of earthworms or large enchytraeids. The Humus Index of these soils was assigned to 1 as for Eumull. Hydromorphic variants of humus forms such as Hydromull, Hydromoder and Hydromor were given the same Humus Index as their aerial counterparts exhibiting similar development of OL, OF, OH, and OM horizons.

Woody plant species growing in the vicinity of sampling plots were identified using Rameau et al. (1989).

\subsection{Statistical analyses}

Densities of the different collembolan species were analyzed by simple correspondence analysis (CA), a multivariate method using the chi-square distance (Greenacre, 1984). Active (main) variables were species, coded by the number of individuals. Contrary to canonical correspondence analysis (Ter Braak, 1987) passive (additional) variables were projected as if they had been used in the analysis but they did not influence to any extent the formation of the factorial axes. In the present study, additional variables were land use units (each coded as one or zero), land use types (each coded as one or zero), species richness and total abundance of collembolan populations (counts), woody species (each coded as one or zero) and the Humus Index (scoring from 1 to 9 ).

In order to give the same weight to all parameters, all variables (discrete as well as continuous) were transformed into $X=(x-m) / s+20$, where $x$ is the original value, $m$ is the mean of a given variable, and $s$ is its standard deviation. The addition to each standardized variable of a constant factor of 20 allows all values to be positive, correspondence analysis dealing only with positive numbers (commonly counts). Following this transformation, factorial coordinates of variables can be interpreted directly in term of their contribution to the factorial axes. Variables were doubled in order to allow for the dual nature of most parameters (the absence of a given species is as important as its presence, low values are as important as high values for measurement data). To each variable $X$ was thus associated a twin $X^{\prime}$ varying in an opposite sense $\left(X^{\prime}=40-X\right)$. Such a doubling proved useful when dealing with ecological gradients (Ponge et al., 1997; Loranger et al., 2001). The transformations used here give to correspondence analysis most properties of the well-known principal components analysis (Hotelling, 1933), while keeping the advantage of the simultaneous projection of rows (variables) and columns (samples) onto the same factorial axes and the robustness due to the principle of distributional equivalence.

In each LUU the variety of land use types was expressed by the Shannon Index, i.e. the number of binary digits (bits) measuring the information given by a sample according to the formula $\sum-p_{i} \log \left(p_{i}\right)$, where $p_{i}$ is the probability given to land use type $i$ among the 16 samples taken in a LUU.

One-way analyses of variance (ANOVA) followed by SNK procedure for comparisons among means were performed on some parameters (Glantz, 1997). Homogeneity of variances between the different LUUs and normal distribution of residuals were tested prior to analysis. The absence of spatial autocorrelation was checked by computing Spearman rank correlation coefficients between adjacent rows and columns of each 16-pt sampling grid. None of these coefficients gave any significant value at the 0.05 level, thus the distance between adjacent samples $(200 \mathrm{~m})$ 
was judged enough to avoid autocorrelation. Given the absence of autocorrelation, the 16 samples taken in each LUU were considered as replicates.

\section{Results}

Table 2 shows the distribution of land use types among the 16 samples taken in each LUU. One of the 16 plots could not be sampled in LUU 4, due to waterlogging. The most widespread land use types were deciduous forests, coniferous forests, and pastures.

Table 3 shows total numbers for springtail species found in every LUU. The most abundant species were the isotomids Folsomia quadriculata (1742 ind.), Isotomiella minor (1517 ind.) and Parisotoma notabilis (1017 ind.).

\subsection{Analysis of collembolan communities}

The matrix analyzed crossed 95 columns (samples) and $89 \times 2$ rows (species, doubled as mentioned above), as main (active) variables. Additional variables (84) were added, in order to facilitate interpretation of factorial axes. Only the first axis of correspondence analysis $(6.5 \%$ of the total variance) was interpretable in terms of ecological factors. The second axis $(5.0 \%$ of the total variance) was roughly a quadratic function of the first axis, i.e. when samples and variables were projected in the plane of the first two axes their cloud formed a parabola, i.e. they exhibited a Guttman or horsehoe effect (Greenacre, 1984). In this case, only the first axis (corresponding to the first eigen value of the distance matrix) was used for projecting the cloud of data. For the sake of clarity only main variables (collembolan species) and additional variables, but not individual samples, will be further considered.

Collembolan species could be projected on factorial axes both as high (original data, with their mean and standard deviation forced to 20 and 1 , respectively), and low values (complement to 40), but for the sake of clarity only high values will be shown and discussed (Fig. 1). Collembolan species were continuously scaled along Axis 1, indicating

Table 2

Distribution of land use types among the six land use units (LUUs)

\begin{tabular}{lrrllll}
\hline & LUU 1 & LUU 2 & LUU 3 & LUU 4 & LUU 5 & LUU 6 \\
\hline Deciduous forest & 16 & 1 & 8 & 0 & 3 & 0 \\
Coniferous forest & 0 & 14 & 2 & 3 & 2 & 0 \\
Clear-cut & 0 & 1 & 0 & 1 & 0 & 0 \\
Hedgerow & 0 & 0 & 0 & 0 & 1 & 0 \\
Hay meadow & 0 & 0 & 4 & 4 & 4 & 0 \\
Pasture & 0 & 0 & 1 & 3 & 6 & 2 \\
Fallow & 0 & 0 & 0 & 1 & 0 & 5 \\
Agricultural field & 0 & 0 & 1 & 3 & 0 & 9 \\
Not sampled & 0 & 0 & 0 & 1 & 0 & 0
\end{tabular}

Sixteen samples were taken in each LUU according to a regular grid, except LUU 4 with 15 samples only due to flooding. that the first factorial axis expressed changes in collembolan communities according to some gradient. Significance of this gradient was shown by the projection of additional variables. The six LUUs were scaled in the order 2, 1, 3, 5, 4,6 , with a large space between 3 and 5 . This corresponded to an opposition between closed (LUUs 1-3, positive side of Axis 1) and open environments (LUUs 4-6, negative side of Axis 1), with a slight departure from the original scaling of increasing intensity of land use ( 1 and 2 were inverted, 4 and 5 were inverted, too). The projection of land use types on Axis 1 reinforced the view that woodland areas were opposed to agricultural areas along Axis 1. This interpretation was strengthened by the fact that species typical of open environments (Ponge, 1980, 1993), such as Isotoma viridis, Lepidocyrtus cyaneus, Deuterosminthurus sulphureus, Sminthurus nigromaculatus, Brachystomella parvula, Sminthurus viridis and Isotoma tigrina, were all on the negative side of Axis 1, whereas species typical of closed environments (Ponge, 1980, 1993), such as Pseudisotoma sensibilis, Xenylla tullbergi, Entomobrya nivalis and Orchesella cincta were all on the positive side (Table 2). Hedgerows exhibited an intermediate position between open and closed environments. Coniferous woodlands did not exhibit profound changes in collembolan communities when compared to deciduous woodlands, as well as clearcut areas, but forest influence was at a maximum in deciduous forests, followed by coniferous forests then by clear-cut areas. On the negative side, pastures, hay meadows and agricultural fields did not exhibit differences in collembolan communities, forming a homogeneous group on the negative side of Axis 1. Changes in total abundance and species richness were also depicted by Axis 1, more species and more individuals per unit surface being present in forested than in agricultural areas. The total abundance of Collembola and the species richness of individual samples were linearly correlated with Axis $1(P<0.001$ and 0.01 , respectively).

Collembolan communities of pastures and hay meadows did not change according to LUUs, contrary to agricultural fields and woodlands (Fig. 2). In LUU 3 and LUU 4 collembolan communities from agricultural fields were not very different from the coniferous woodland counterparts, as exemplified by the projection of the corresponding passive variables at the same level of Axis 1. Far from the origin on the positive side of Axis 1 (thus most typical for forest environments) were deciduous woodlands from LUU 1 and LLU 3, and coniferous woodlands from LUU 2, other forested sites being less different from open environments.

Discrepancies between forested sites were reflected in the projection of woody plant species on Axis 1 (Fig. 3). Although $Q$. petraea, $F$. sylvatica and $A$. alba were far from the origin on the positive side of Axis 1, other timber such as $P$. abies and $P$. menziesii were near the origin, not far from open environments. Thus collembolan communities from spruce and Douglas fir plantations in agricultural landscapes (LUUs 3-6) differed less from agricultural fields and 
Table 3

Collembolan species and main features of collembolan populations in the six sampled land use units

\begin{tabular}{|c|c|c|c|c|c|c|c|c|c|}
\hline & & Axis 1 & $\begin{array}{l}\text { LUU } 1 \\
(n=16)\end{array}$ & $\begin{array}{l}\text { LUU } 2 \\
(n=16)\end{array}$ & $\begin{array}{l}\text { LUU } 3 \\
(n=16)\end{array}$ & $\begin{array}{l}\text { LUU } 4 \\
(n=15)\end{array}$ & $\begin{array}{l}\text { LUU } 5 \\
(n=16)\end{array}$ & $\begin{array}{l}\text { LUU } 6 \\
(n=16)\end{array}$ & Total \\
\hline $\mathrm{AFU}$ & Allacma fusca & 0.003 & 0 & 1 & 0 & 1 & 0 & 0 & 2 \\
\hline AGR & Anurida granaria & -0.011 & 0 & 0 & 0 & 0 & 0 & 1 & 1 \\
\hline AUN & Anurida uniformis & -0.011 & 0 & 0 & 0 & 0 & 0 & 2 & 2 \\
\hline $\mathrm{ABI}$ & Arrhopalites bifidus & 0.003 & 0 & 0 & 2 & 1 & 0 & 0 & 3 \\
\hline ASP & Arrhopalites sp. & 0.007 & 1 & 0 & 0 & 0 & 0 & 0 & 1 \\
\hline CAR & Ceratophysella armata & 0.004 & 26 & 2 & 0 & 0 & 0 & 0 & 28 \\
\hline $\mathrm{CDE}$ & Ceratophysella denticulata & -0.012 & 0 & 2 & 1 & 15 & 0 & 0 & 18 \\
\hline CLU & Ceratophysella luteospina & 0.009 & 0 & 0 & 2 & 0 & 1 & 3 & 6 \\
\hline CAL & Cyphoderus albinol & -0.007 & 0 & 0 & 1 & 0 & 0 & 0 & 1 \\
\hline DSU & Deuterosminthurus sulphureus & -0.012 & 1 & 0 & 3 & 1 & 1 & 6 & 12 \\
\hline DFU & Dicyrtoma fusca & -0.005 & 0 & 0 & 0 & 1 & 1 & 0 & 2 \\
\hline DMI & Dicyrtomina minuta & -0.006 & 3 & 0 & 1 & 5 & 0 & 4 & 13 \\
\hline EMU & Entomobrya multifasciata & -0.006 & 1 & 0 & 0 & 1 & 0 & 3 & 5 \\
\hline ENI & Entomobrya nivalis & 0.005 & 0 & 1 & 0 & 1 & 0 & 0 & 2 \\
\hline FQS & Fasciosminthurus quinquefasciatus & -0.002 & 0 & 0 & 0 & 0 & 0 & 3 & 3 \\
\hline FCA & Folsomia candida & -0.006 & 0 & 0 & 0 & 4 & 0 & 0 & 4 \\
\hline FFI & Folsomia fimetaria & -0.008 & 0 & 0 & 11 & 0 & 0 & 0 & 11 \\
\hline FQU & Folsomia quadrioculata & 0.025 & 446 & 502 & 378 & 221 & 156 & 39 & 1742 \\
\hline FCL & Friesea claviseta & 0.001 & 0 & 7 & 0 & 0 & 1 & 4 & 12 \\
\hline FMI & Friesea mirabilis & 0.003 & 6 & 0 & 0 & 0 & 0 & 0 & 6 \\
\hline FTR & Friesea truncata & 0.029 & 46 & 163 & 83 & 2 & 29 & 46 & 369 \\
\hline HNI & Heteromurus nitidus & -0.007 & 0 & 0 & 2 & 4 & 1 & 0 & 7 \\
\hline IAN & Isotoma antennalis & -0.008 & 0 & 0 & 0 & 39 & 0 & 3 & 42 \\
\hline ITI & Isotoma tigrina & -0.001 & 0 & 0 & 0 & 0 & 11 & 2 & 13 \\
\hline IVI & Isotoma viridis & -0.019 & 1 & 0 & 128 & 46 & 61 & 176 & 412 \\
\hline IMI & Isotomiella minor & 0.024 & 502 & 291 & 359 & 87 & 136 & 142 & 1517 \\
\hline IPR & Isotomodes productus & 0.000 & 0 & 1 & 0 & 0 & 0 & 6 & 7 \\
\hline IPA & Isotomurus palustris & -0.020 & 0 & 0 & 25 & 87 & 1 & 33 & 146 \\
\hline LLA & Lepidocyrtus lanuginosus & 0.002 & 36 & 49 & 53 & 32 & 99 & 33 & 302 \\
\hline LLI & Lepidocyrtus lignorum & -0.018 & 2 & 2 & 38 & 43 & 50 & 23 & 158 \\
\hline LLU & Lipothrix lubbocki & 0.011 & 13 & 11 & 6 & 0 & 0 & 0 & 30 \\
\hline MMI & Megalothorax minimus & 0.025 & 48 & 107 & 77 & 14 & 54 & 30 & 330 \\
\hline MBE & Mesaphorura betschi & 0.009 & 0 & 1 & 0 & 0 & 0 & 0 & 1 \\
\hline MJE & Mesaphorura jevanica & 0.022 & 90 & 144 & 136 & 0 & 14 & 12 & 396 \\
\hline MLE & Mesaphorura leitzaensis & 0.011 & 1 & 19 & 0 & 0 & 0 & 0 & 20 \\
\hline MMA & Mesaphorura macrochaeta & 0.010 & 86 & 247 & 107 & 43 & 118 & 157 & 758 \\
\hline MYO & Mesaphorura yosii & 0.021 & 51 & 50 & 8 & 5 & 3 & 0 & 117 \\
\hline MPY & Micranurida pygmaea & 0.013 & 8 & 20 & 4 & 0 & 6 & 1 & 39 \\
\hline MSE & Micranurida sensillata & 0.004 & 1 & 9 & 0 & 0 & 0 & 0 & 10 \\
\hline MAB & Micraphorura absoloni & 0.015 & 0 & 2 & 6 & 0 & 0 & 0 & 8 \\
\hline NMU & Neanura muscorum & 0.014 & 2 & 6 & 4 & 1 & 1 & 0 & 14 \\
\hline NMI & Neelides minutus & 0.011 & 3 & 0 & 2 & 0 & 0 & 0 & 5 \\
\hline NRA & Neotullbergia ramicuspis & -0.011 & 0 & 0 & 0 & 0 & 0 & 1 & 1 \\
\hline OCR & Oncopodura crassicornis & 0.016 & 0 & 0 & 1 & 0 & 0 & 0 & 1 \\
\hline OPS & Onychiuroides pseudogranulosus & 0.008 & 24 & 1 & 0 & 2 & 0 & 0 & 27 \\
\hline OCE & Onychiurus cebennarius & 0.019 & 33 & 11 & 125 & 0 & 3 & 2 & 174 \\
\hline OJU & Onychiurus jubilarius & -0.008 & 0 & 0 & 0 & 2 & 6 & 1 & 9 \\
\hline OCI & Orchesella cincta & 0.002 & 0 & 0 & 2 & 18 & 0 & 6 & 26 \\
\hline OQU & Orchesella quinquefasciata & -0.008 & 0 & 0 & 0 & 0 & 0 & 1 & 1 \\
\hline OVI & Orchesella villosa & -0.008 & 0 & 0 & 0 & 0 & 0 & 1 & 1 \\
\hline PCA & Paratullbergia callipygos & 0.010 & 54 & 1 & 26 & 14 & 47 & 8 & 150 \\
\hline PNO & Parisotoma notabilis & -0.014 & 55 & 75 & 244 & 97 & 323 & 223 & 1017 \\
\hline PFL & Pogonognathellus flavescens & 0.008 & 14 & 5 & 11 & 0 & 4 & 0 & 34 \\
\hline PMI & Proisotoma minima & 0.018 & 0 & 5 & 0 & 0 & 1 & 1 & 7 \\
\hline PAR & Protaphorura armata & -0.019 & 26 & 51 & 46 & 73 & 85 & 139 & 420 \\
\hline PME & Protaphorura meridiata & -0.003 & 2 & 3 & 36 & 0 & 0 & 0 & 41 \\
\hline
\end{tabular}




\begin{tabular}{|c|c|c|c|c|c|c|c|c|c|}
\hline & & Axis 1 & $\begin{array}{l}\text { LUU } 1 \\
(n=16)\end{array}$ & $\begin{array}{l}\text { LUU } 2 \\
(n=16)\end{array}$ & $\begin{array}{l}\text { LUU } 3 \\
(n=16)\end{array}$ & $\begin{array}{l}\text { LUU } 4 \\
(n=15)\end{array}$ & $\begin{array}{l}\text { LUU } 5 \\
(n=16)\end{array}$ & $\begin{array}{l}\text { LUU } 6 \\
(n=16)\end{array}$ & Total \\
\hline PPR & Protaphorura prolata & 0.000 & 3 & 0 & 2 & 3 & 0 & 0 & 8 \\
\hline PPA & Pseudachorutes parvulus & 0.013 & 9 & 5 & 0 & 0 & 5 & 1 & 20 \\
\hline PBI & Pseudanurophorus binoculatus & 0.000 & 1 & 0 & 0 & 0 & 0 & 0 & 1 \\
\hline PSE & Pseudisotoma sensibilis & 0.027 & 3 & 138 & 10 & 0 & 6 & 0 & 157 \\
\hline PAL & Pseudosinella alba & -0.015 & 0 & 0 & 1 & 3 & 21 & 36 & 61 \\
\hline PIL & Pseudosinella illiciens & -0.008 & 0 & 0 & 0 & 0 & 0 & 5 & 5 \\
\hline PMA & Pseudosinella mauli & 0.015 & 3 & 7 & 1 & 0 & 6 & 0 & 17 \\
\hline SPA & Sminthurides parvulus & -0.008 & 0 & 0 & 0 & 1 & 3 & 4 & 8 \\
\hline SSC & Sminthurides schoetti & -0.015 & 3 & 1 & 5 & 14 & 3 & 6 & 32 \\
\hline SAU & Sminthurinus aureus & -0.022 & 1 & 3 & 24 & 19 & 68 & 45 & 160 \\
\hline SNI & Sminthurinus niger & -0.012 & 0 & 0 & 0 & 1 & 0 & 0 & 1 \\
\hline SSI & Sminthurinus signatus & 0.022 & 9 & 12 & 10 & 7 & 0 & 1 & 39 \\
\hline SNS & Sminthurus nigromaculatus & -0.005 & 0 & 0 & 0 & 0 & 0 & 1 & 1 \\
\hline SVI & Sminthurus viridis & -0.006 & 0 & 0 & 1 & 18 & 0 & 3 & 22 \\
\hline SPU & Sphaeridia pumilis & -0.024 & 3 & 1 & 30 & 54 & 131 & 71 & 290 \\
\hline SED & Spinonychiurus edinensis & -0.007 & 0 & 0 & 10 & 0 & 0 & 2 & 12 \\
\hline SVA & Stenacidia violacea & -0.007 & 0 & 0 & 2 & 6 & 1 & 0 & 9 \\
\hline SDE & Stenaphorura denisi & -0.005 & 0 & 0 & 0 & 1 & 0 & 0 & 1 \\
\hline SQU & Stenaphorura quadrispina & -0.002 & 0 & 0 & 0 & 2 & 0 & 13 & 15 \\
\hline TMI & Tomocerus minor & 0.001 & 0 & 2 & 0 & 8 & 0 & 0 & 10 \\
\hline VAR & Vertagopus arboreus & 0.004 & 0 & 0 & 2 & 0 & 0 & 0 & 2 \\
\hline WAN & Willemia anophthalma & 0.018 & 5 & 56 & 2 & 0 & 2 & 3 & 68 \\
\hline WDE & Willemia denisi & 0.013 & 18 & 0 & 4 & 0 & 0 & 0 & 22 \\
\hline WIN & Willemia intermedia & 0.008 & 0 & 0 & 17 & 0 & 3 & 0 & 20 \\
\hline WNI & Willowsia nigromaculata & -0.006 & 0 & 0 & 0 & 0 & 0 & 1 & 1 \\
\hline XGR & Xenylla grisea & 0.004 & 28 & 0 & 1 & 0 & 2 & 0 & 31 \\
\hline XTU & Xenylla tullbergi & 0.016 & 1 & 52 & 0 & 5 & 8 & 0 & 66 \\
\hline \multirow[t]{5}{*}{ XAR } & Xenyllodes armatus & 0.025 & 13 & 30 & 11 & 0 & 0 & 0 & 54 \\
\hline & Total species richness & & 43 & 42 & 51 & 44 & 42 & 47 & \\
\hline & Mean abundance $( \pm \mathrm{SE})$ & & $105 \pm 11$ & $131 \pm 25$ & $129 \pm 27$ & $68 \pm 13$ & $92 \pm 16$ & $88 \pm 16$ & \\
\hline & Mean species richness $( \pm \mathrm{SE})$ & & $14 \pm 1$ & $13 \pm 1$ & $11 \pm 1$ & $10 \pm 1$ & $11 \pm 1$ & $12 \pm 1$ & \\
\hline & Humus Index $( \pm \mathrm{SE})$ & & $5.4 \pm 0.4$ & $6.1 \pm 0.3$ & $2.9 \pm 0.6$ & $2.6 \pm 0.6$ & $2.0 \pm 0.6$ & $1.4 \pm 0.3$ & \\
\hline
\end{tabular}

pastures than they differed from old beech and oak forests or from silver fir plantations in forested landscapes (LUUs 1 and 2). Trees typical of early stages of forest succession (abandoned fields) or of woodland borders, such as Prunus spinosa L., Crataegus monogyna Lacq., Malus sylvestris Mill., Pyrus pyraster Burgsd., Cytisus scoparius (L.) Link, Salix sp., Acer pseudoplatanus L., Prunus avium L., and Sambucus racemosa L., were nearly at the same position as planted spruce and Douglas fir, indicating that collembolan communities of Douglas fir and Norway spruce plantations did not differ to any great extent from early stages of forest succession (old fallows).

The projection of humus forms along Axis 1 revealed that forest samples exhibited thick organic horizons (typically Dysmoder and Amphimull) as opposed to agricultural fields and meadows which were characterized by Eumull (Fig. 4). The Humus Index exhibited a highly significant linear correlation with Axis $1(P<0.001)$. Thus Axis 1 reflected also a decreasing trend of soil biological activity from open to closed environments. This interpretation was reinforced by the position of all species known to live only in raw humus (Mor, Dysmoder) and other acid humus forms, i.e. Sminthurinus signatus, Mesaphorura yosii, Willemia anophthalma, Proisotoma minima, X. tullbergi, Pseudosinella mauli and Micraphorura absoloni on the positive side of Axis 1, and the projection of all species known to live only in Eumull, i.e. Sminthurinus aureus, Pseudosinella alba, $P$. notabilis, Onychiurus jubilarius, Heteromurus nitidus and Stenaphorura denisi, on the negative side of Axis 1. The position of Agricultural Moder is worthy of note, since it was projected not far from the origin, thus far from samples typical of agricultural fields (Fig. 1). This indicated that its species composition differed somewhat from Eumull, showing similarities with forest humus forms with thick litter horizons, despite the total absence of litter. Examination of individual samples revealed that acidophilic species such as S. signatus, W. anophthalma and M. yosii were present in Agricultural Moder (four samples, all but one in LUU 4), and not in agricultural soils with Eumull (nine samples, all but one in LUU 6). On the contrary, the acidointolerant species $P$. alba was present in agricultural soils with Eumull, not in Agricultural Moder. In both agricultural crop environments, the open-habitat species I. viridis and $L$. cyaneus were present.

Waterlogging (and the associated humus forms Hydromull, Hydromoder and Hydromor) did not influence species 


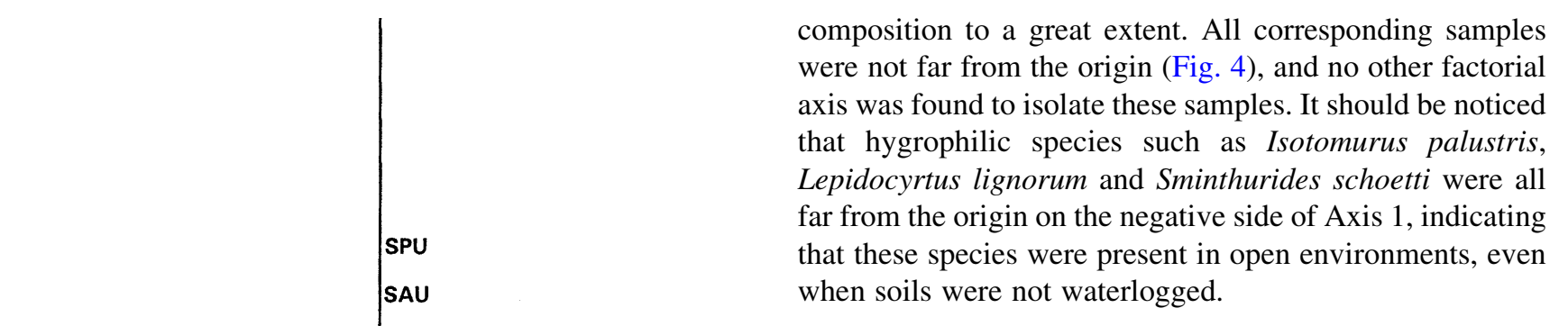

\subsection{Biodiversity and land use variety}

The total species richness (cf. 40-50 species found in each LUU) showed little variation between LUUs (Table 3), i.e. each contained around half the total number of species found in the whole sample (89). In contrast, the individual species richness (the number of species found in a core sample $5 \mathrm{~cm}$ diameter and $10 \mathrm{~cm}$ depth) varied markedly among the six LUUs (Fig. 5). Analysis of variance (ANOVA) revealed a significant heterogeneity according to LUUs $(F=2.7, P<0.05)$, most difference (significant at 0.05 level) being between LUU 1 and LUU 4. The curve formed by the six mean values was saddle-shaped, indicating a continuous decrease from LUU 1 to LUU 4 followed by a continuous increase up to LUU 6, although the latter did not reach the level of species richness exhibited by LUU 1.

The distribution of land use types (Table 2) can be used in each LUU to measure the variety of the landscape. The Shannon Index (Shannon, 1948) allowed to compare the species richness of individual samples with a quantitative landscape factor (Fig. 5). The curve of land use variety mirrored that of local species richness, the latter increasing then decreasing in contrast to the former, which was better exemplified by a correlation plot (Fig. 6). The least variation in land use occurred in a square kilometer, the more species occurred together at the scale of the core sampler.

The hypothesis that negative effects of landscape variety on local species richness could be due to changes in the dominant land use types was tested by examining individual trends followed by the main land use types when crossing several LUUs. Given results from correspondence analysis, coniferous and deciduous forests were pooled into an unique woodland category. Accordingly, pastures, hay meadows and agricultural crops (cereals, rape) formed the grassland category. It appeared that in grassland the species richness of individual samples exhibited only a slight increase from LUU 3 to LUU 6 (no grassland occurred in LUU 1 and LUU 2), while strong variation according to LUUs was observed in the woodland category (Table 4). The decrease observed from LUU 1 to LUU 4 when taking only woodland into account (approximating 50\%) was more pronounced than when all land use types were included in the calculation (Fig. 5). Thus the decrease in biodiversity observed from LUU 1 to LUU 4 concerned only woodland.

Examination of individual data did not reveal any meaningful trend of extinction of species. Rather, a collapse
Fig. 1. Correspondence analysis. Projection of collembolan species (three-letter codes according to Table 3), population parameters (higher values in bold type, lower values in italic type), land use units (numbers in boxes) and land use types (underlined) on Axis 1. Position of the origin is indicated by an arrow. Positive and negative Axis 1 coordinates are on the lower and upper side, respectively. 


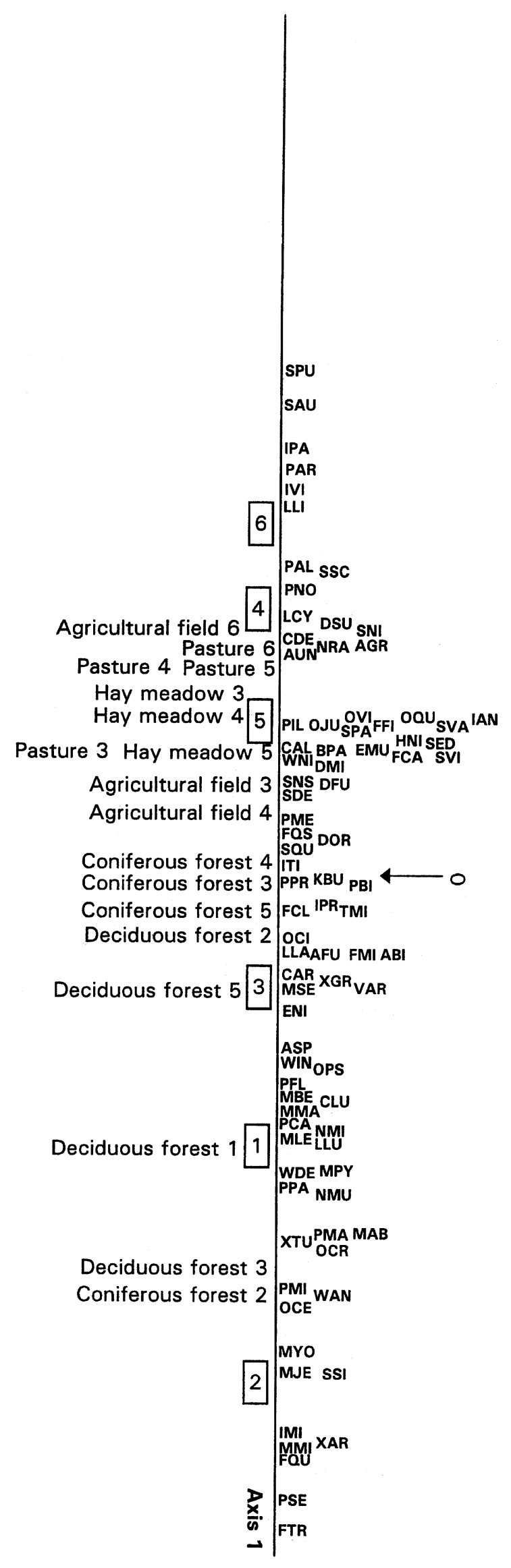

in the total population was observed in woodland samples taken in LUU 4 (Table 4), which could explain the observed fall in local species richness. Such changes in total abundance of Collembola were never observed in grassland samples.

\section{Discussion}

In the Morvan Nature Regional Park, land use intensification caused changes in species composition, total abundance and species richness of collembolan communities. The first axis of correspondence analysis showed a global trend contrasting forest sites (closed, with accumulation of organic matter at the ground surface) with agricultural sites (open, with rapid incorporation of organic matter). The Humus Index (Ponge et al., 2002) showed an improvement of soil biological activity in grassland, compared to woodland soils. This may result from a combination of factors, all of them acting in the same direction: choice of the best soils for crop and cattle production (Braojos et al., 1997), more heat and water in the soil (Jansson, 1987), use of organic manure or fertilizers to improve primary production (Koerner et al., 1997). Changes in species composition followed changes in both microclimate and edaphic parameters, as revealed by the replacement of woodland species such as $P$. sensibilis by grassland species such as I. viridis (Szeptycki, 1967; Ponge, 1993), and the replacement of acidophilic species, such as $P$. mauli and S. signatus, by acido-intolerant species such as P. alba and S. aureus (Ponge, 1993). This could allow the species composition of collembolan communities to be used as an indicator of the intensification of land use, provided underlying ecological factors are clearly identified. This is an important point to be highlighted, given the fuzzy contour of the human factor. For instance, Hågvar and Abrahamsen (1990), studying a transect through a naturally lead-contaminated site (an abandoned mine), observed that the isotomid Isotoma olivacea (syn. I. tigrina, present in our sample) was favored by lead contamination, compared to all other species, because of its higher abundance at the most polluted site. Examination of their site description allowed us to reinterpret the abundance of this species at the most polluted site as resulting from the collapse of tree vegetation. In a similar study on a zinc-polluted abandoned field Gillet and Ponge (2003) observed that typical grassland species such as $L$. cyaneus were abundant at the most polluted site, due to collapse of the poplar plantation. Other instances concern atmospheric pollution, most effects of

Fig. 2. Correspondence analysis. Projection of collembolan species (threeletter codes according to Table 3), land use units (numbers in boxes) and land use types separated by land use units on Axis 1. Position of the origin is indicated by an arrow. Positive and negative Axis 1 coordinates are on the lower and upper side, respectively. 


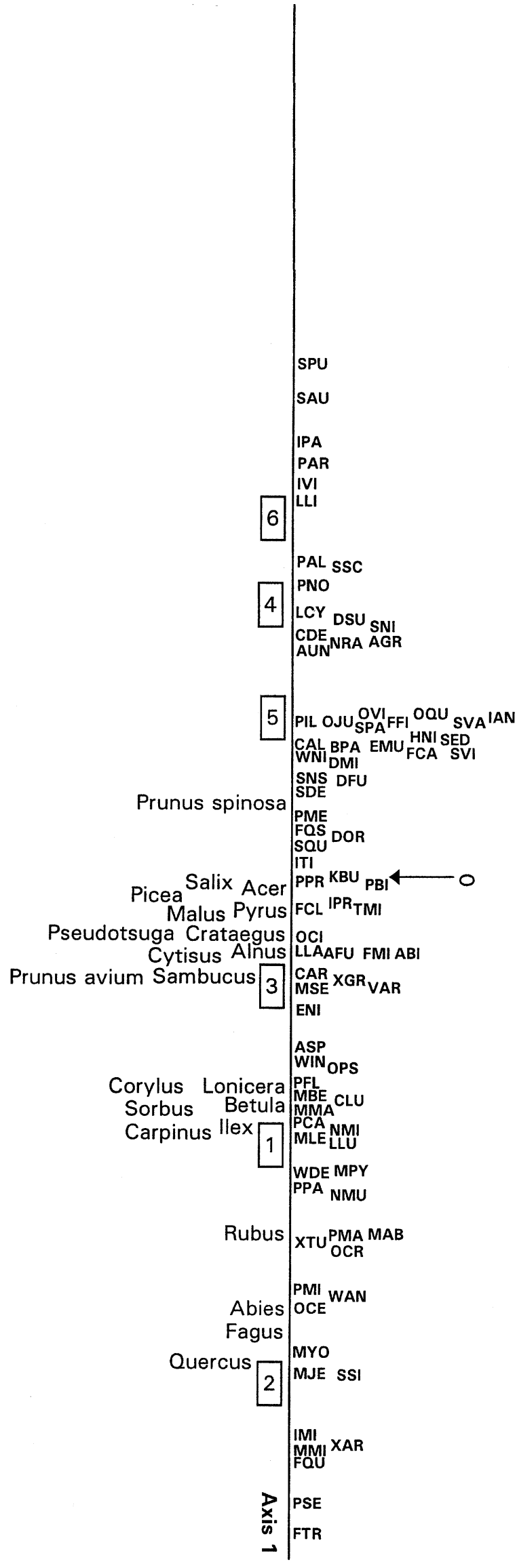

which on the soil are due to acidification, as this has been repeatedly observed in northern and Central Europe (Tamm and Hallbäcken, 1988; Hambuckers and Remacle, 1987; Falkengren-Grerup, 1987). In this latter case, the effects of human activities are exactly opposed to those recorded in the present study, where most acid soils are those least subject to human influence, i.e. soils from old deciduous forests.

The decrease in local species richness observed when the landscape becomes more diversified, in the absence of any decrease in regional species richness, seems at first sight more difficult to interpret. The independence between regional $(\gamma)$ and local $(\alpha)$ diversity of collembolan populations has been already observed in temperate grassland communities (Winkler and Kamplicher, 2000) but it conflicts with studies on macroarthropod (Halme and Niemelä, 1993; Duelli and Obrist, 1998; David et al., 1999) and plant communities (Tilman, 1999). Some explanation can be found in the past history of the sites and in the scale at which these tiny soil animals are living. We have shown that the shift from woodland to grassland (and associated changes in climate, soil and vegetation) was the main factor explaining changes in soil collembolan communities. Other studies indicate the rates at which collembolan communities may recover (or shift to another equilibrium stage) following changes in vegetation cover. Cyclic changes in the species composition of collembolan communities have been observed to occur at the scale of centuries in near-natural mountain spruce forests, following cyclic changes in soil acidity in the course of vegetation dynamics (Loranger et al., 2001). In such forest mosaics, the rate of change and the availability of refuges allow the progressive recovery of communities as far as environmental conditions (micro-climate, soil chemistry, litter quality) return to original conditions. On the contrary, it has been observed that sudden deforestation (Takeda, 1981; Gers and Izarra, 1983; Mateos and Selga, 1991) as well as afforestation (Jordana et al., 1987) causes a rapid collapse in total abundance and species richness of collembolan communities. Cassagnau (1990) underlined that in both cases rarefaction of species typical of past land use was more rapid than immigration of species typical of the new environment thus created, which could explain the decrease in biodiversity observed in landscapes most subject to recent changes in land use, compared to more stable landscapes. Along our gradient of intensification of land use (LUU 1 to LUU 6) both sides did not exhibit any profound changes over the last decades. For instance coniferous plantations in LUU 2 (mostly silver fir) occurred in previous old deciduous

Fig. 3. Correspondence analysis. Projection of collembolan species (threeletter codes according to Table 3), land use units (numbers in boxes) and woody plant species on Axis 1. Position of the origin is indicated by an arrow. Positive and negative Axis 1 coordinates are on the lower and upper side, respectively. 


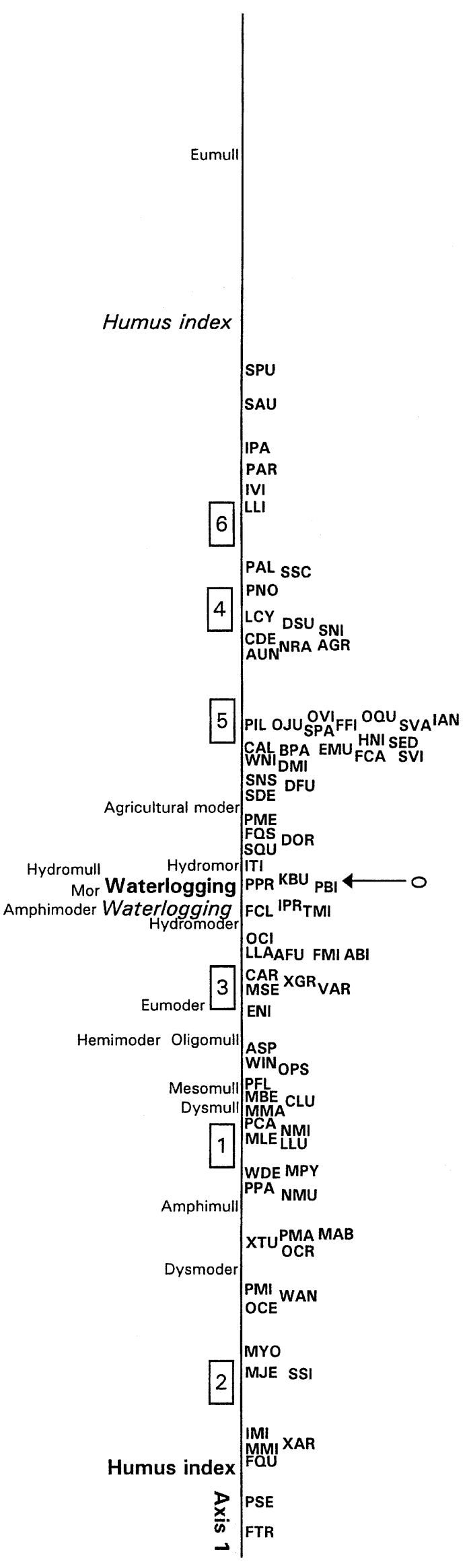

forests, as ascertained by the continuous presence of relict beech and oak. Thus no sharp transition occurred in the course of time, despite clear-cut operations and shift from hardwood to softwood (remind that clear-cut areas did not exhibit change in species composition, too). Most severe changes in land use occurred in zones intermediate between wide forested areas (on the less fertile soils) and plain land devoted to cereal crops for a long time (on the more fertile soils). The grassland past of present Norway spruce or Douglas fir plantations (more especially in LUU 4) can be ascertained by the presence of certain pasture plants still growing in the understory. Over the last 10 decades the Morvan region has been subject to severe changes in land use (Braojos et al., 1997), due to (i) abandonment of fire wood silviculture at the turn of the 19th century, (ii) progressive abandonment of agriculture after the second world war, (iii) recent increase of Christmas-tree fields. Variegated landscapes (LUUs 3-5) reflects best such recent shift in land use, afforestation of previous grassland occurring at a rate probably too rapid for the development of adapted soil animal communities. We hypothesize that the imbalance between immigration rates of new species and changes in land use will not occur for colonizers that have better dispersal mechanisms such as most plants and winged insects. The stability of regional biodiversity observed along our gradient of land use intensification can be ascribed to a compensation between an increase in the number of species in more variegated landscapes (through the addition of grassland to woodland communities) and the above mentioned lost of species resulting from too rapid changes in land use.

It was surprising to see that cereal crops, which undergo heavy disturbance by deep ploughing, pesticides and the absence of plant cover over a large part of the year, did not display any significant reduction in total abundance and species richness when compared with hay meadows and permanent pastures. Studies on agricultural soils showed a vertical redistribution of collembolan populations following annual ploughing and burying of crop residues (Van Amelsvoort et al., 1988; Petersen, 2000), which probably helps to maintain abundance of food at a depth where these tiny animals are protected from winter frost and summer drought. This may compensate for the absence of litter and plant cover during cold and dry seasons. Moreover, the cyclicity of changes taking place in agricultural soils may allow communities to adapt themselves to changing conditions, by synchronizing their population dynamics with the cycle of change, as this has been demonstrated in

Fig. 4. Correspondence analysis. Projection of collembolan species (threeletter codes according to Table 3), Humus Index (higher values in bold type, lower values in italic type), waterlogging (presence in bold type, absence in italic type) and humus forms on Axis 1. Position of the origin is indicated by an arrow. Positive and negative Axis 1 coordinates are on the lower and upper side, respectively. 


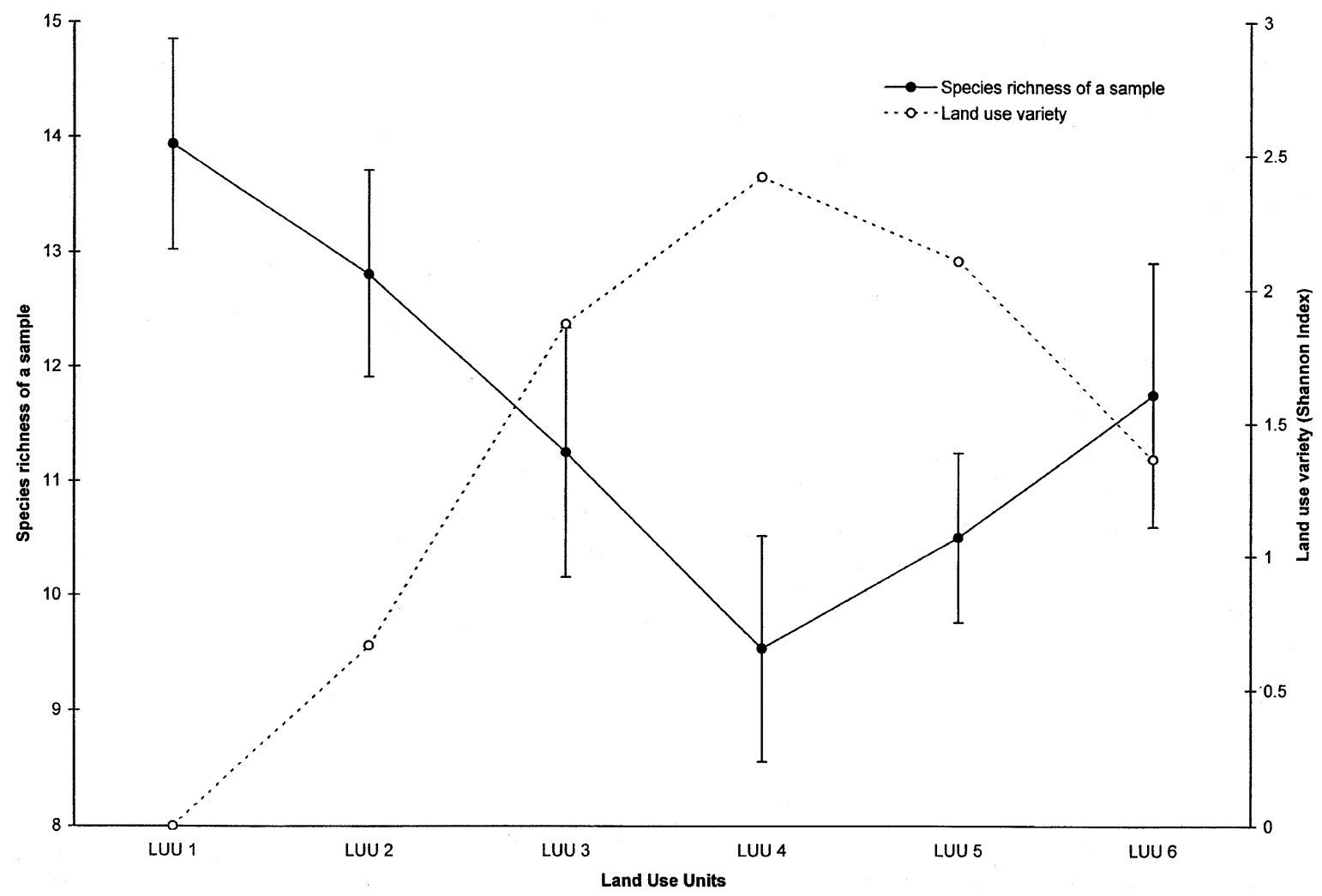

Fig. 5. Distribution of local species richness of collembolan communities and land use variety (Shannon Index) over a gradient of land use intensity (LUUs 1-6). Vertical bars indicate standard errors of the means.

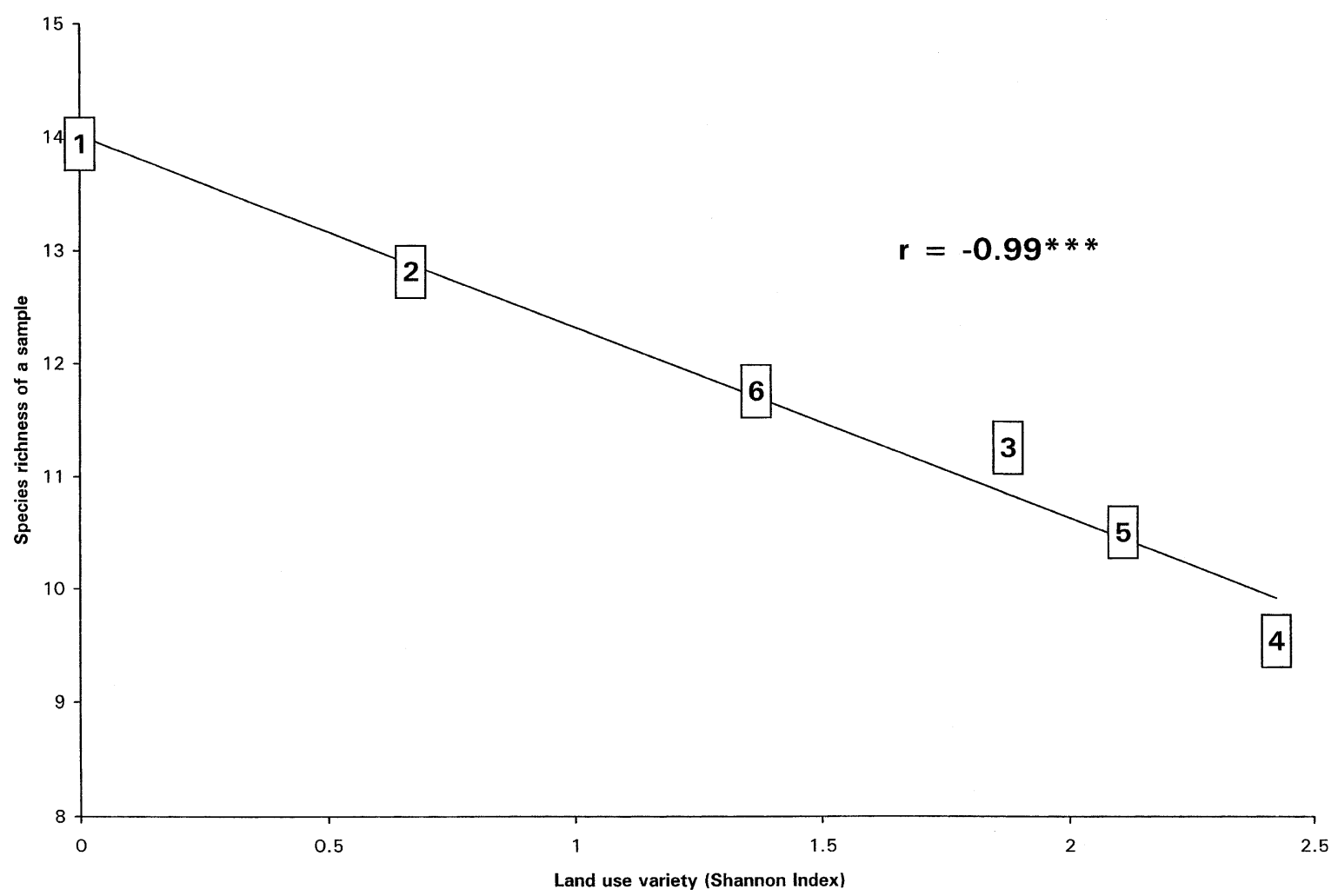

Fig. 6. Correlation plot crossing local species richness of collembolan communities and land use variety (measured by the Shannon Index). Numbers in boxes represent the six land use units. 
Table 4

Total abundance and number of species of Collembola in individual core samples (5 cm diameter, $10 \mathrm{~cm}$ depth) according to main land use types in the six land use units investigated (mean followed by standard error)

\begin{tabular}{|c|c|c|c|c|}
\hline & \multicolumn{2}{|l|}{ Abundance } & \multicolumn{2}{|c|}{ Species richness } \\
\hline & Woodland & Grassland & Woodland & Grassland \\
\hline LUU 1 & $105 \pm 11$ & & $13.9 \pm 0.9$ & \\
\hline LUU 2 & $122 \pm 24$ & & $12.7 \pm 1.0$ & \\
\hline LUU 3 & $131 \pm 37$ & $126 \pm 42$ & $11.9 \pm 1.4$ & $10.2 \pm 1.9$ \\
\hline LUU 4 & $37 \pm 21$ & $83 \pm 17$ & $7.7 \pm 2.2$ & $10.3 \pm 1.2$ \\
\hline LUU 5 & $71 \pm 10$ & $105 \pm 24$ & $10.2 \pm 0.8$ & $10.7 \pm 1.1$ \\
\hline LUU 6 & & $102 \pm 22$ & & $11.2 \pm 1.6$ \\
\hline
\end{tabular}

forest soils (Usher, 1970; Takeda, 1987; Gauer, 1997). In short, it can be said that cyclic disturbance is not disturbance at all (Odum, 1969; Chernova and Kuznetsova, 2000). On the contrary, non-cyclic changes may damage communities until new, better adapted communities, develop, mainly through immigration of new species. Time is important in this respect (Burges, 1960). Recovery of collembolan populations may last decades or centuries, depending on dispersal capabilities of the species, proximity of possible sources for the immigration of better adapted species, and absence of a new shift in land use during the meantime (Bengtsson et al., 1994; Mebes and Filser, 1997; Ojala and Huhta, 2001).

Another example of the effect of land use intensification on the structure and diversity of soil animal communities can be found in a study of nematodes in tropical soils by Bloemers et al. (1997). These authors did not detect any profound influence of slash-and-burn and heavy machinery deforestation on the trophic structure of nematode communities, as expressed by the Maturity Index (Bongers, 1990), but they observed a $40 \%$ decrease in species richness. This short-term depressive effect can be considered as in line with our results on temperate Collembola. Here too, most disturbances resulted from the abrupt passage from forest to open environments, the reverse (plantation of trees on previous agricultural soils) being not considered.

The results of this study show that a critical assessment is required over the choice of Collembola as bioindicators of land use intensification. On one hand we have seen that collembolan communities differ clearly between low (forest) and high (crop) land use intensity and that they could be used to some extent as bioindicators of this factor, in spite of a correlation with other ecological factors (soil acidity) not directly related to human activities. On the other hand, we have also shown that it is necessary to take into account landscape dynamics. This second observation points to limits for the use of Collembola, and more generally, animal communities, for the bioindication of land use intensity or land use type, since they do not adapt rapidly to changes in land use. The aim of bioindication must be clearly expressed before this interesting tool could be used for monitoring or predicting biodiversity.

\section{Acknowledgements}

This study was part of the European Community program BioAssess EVK2-CT-1999-00041 (directed by Allan Watt, $\mathrm{CEH}$, Aberdeen, UK), which is greatly acknowledged for financial support and fruitful exchange of ideas between partners. Many thanks are due to Dr John Measey for improvement of the English language.

\section{References}

Bengtsson, G., Rundgren, S., Sjögren, M., 1994. Modelling dispersal distances in a soil gradient: the influence of metal resistance, competition, and experience. Oikos 71, 13-23.

Bloemers, G.F., Hodda, M., Lambshead, P.J.D., Lawton, J.H., Wanless, F.R., 1997. The effects of forest disturbance on diversity of tropical soil nematodes. Oecologia 111, 575-582.

Bongers, T., 1990. The maturity index: an ecological measure of environmental disturbance based on nematode species composition. Oecologia 83, 14-19.

Braojos, F.R., Diouf, M., Maxime, F., 1997. Études sur l'agriculture autour du Mont Beuvray. In: Buchsenschutz, O., Richard, H. (Eds.), L Environnementdu Mont Beuvray, Centre Archéologique Européen, Glux-en-Glenne, pp. 99-121.

Bretfeld, G., 1999. Synopses on palaearctic Collembola. II. Symphypleona. Abhandlungen und Berichte des Naturkundemuseums Görlitz 71, $1-318$.

Brêthes, A., Brun, J.J., Jabiol, B., Ponge, J.F., Toutain, F., 1995. Classification of forest humus forms: a French proposal. Annales des Sciences Forestières 52, 535-546.

Burges, A., 1960. Time and size as factors in ecology. Journal of Ecology 48, 273-285.

Cassagnau, P., 1990. Des Hexapodes vieux de 400 millions d'années: les Collemboles. II. Biogéographie et écologie. L'Année Biologique 29 (1), 39-69.

Chagnon, M., Hébert, C., Paré, D., 2000. Community structures of Collembola in sugar maple forests: relations to humus type and seasonal trends. Pedobiologia 44, 148-174.

Chernova, N.M., Kuznetsova, N.A., 2000. Collembolan community organization and its temporal predictability. Pedobiologia 44, $451-466$.

Cortet, J., Gomot-De Vauflery, A., Poinsot-Balaguer, N., Gomot, L., Texier, C., Cluzeau, D., 1999. The use of invertebrate soil fauna in monitoring pollutant effects. European Journal of Soil Biology 35, $115-134$.

Crouau, Y., Chenon, P., Gisclard, C., 1999. The use of Folsomia candida (Collembola, Isotomidae) for the bioassay of xenobiotic substances and soil pollutants. Applied Soil Ecology 12, 103-111.

David, J.F., Devernay, S., Loucougaray, G., Le Floc'h, E., 1999. Belowground biodiversity in a Mediterranean landscape: relationships between saprophagous macroarthropod communities and vegetation structure. Biodiversity and Conservation 8, 753-767. 
Didden, W.A.M., 1990. Involvement of Enchytraeidae (Oligochaeta) in soil structure evolution in agricultural fields. Biology and Fertility of Soils 9, 152-158.

Duelli, P., Obrist, M.K., 1998. In search of the best correlates for local organismal biodiversity in cultivated areas. Biodiversity and Conservation 7, 297-309.

Duelli, P., Studer, M., Marchand, I., Jakob, S., 1990. Population movements of arthropods between natural and cultivated areas. Biological Conservation 54, 193-207.

Falkengren-Grerup, U., 1987. Long-term changes in $\mathrm{pH}$ of forest soils in southern Sweden. Environmental Pollution 43, 79-90.

Fjellberg, A., 1998. The Collembola of Fennoscandia and Denmark. I. Poduromorpha, Brill, Leiden, 184 pp.

Gauer, U., 1997. Collembola in Central Amazon inundation forests: strategies for surviving floods. Pedobiologia 41, 69-73.

Gers, C., de Izarra, D.C., 1983. Rupture de l'équilibre biocénotique des populations de Collemboles à la station de ski de CalmazelleFormiguères (Pyrénées Orientales). Bulletin de la Société d'Histoire Naturelle de Toulouse 119, 63-69.

Gillet, S., Ponge, J.F., 2003. Changes in species assemblages and diets of Collembola along a gradient of metal pollution. Applied Soil Ecology $22,127-138$

Gisin, H., 1943. Ökologie und Lebengemeinschaften der Collembolen im schweizerischen Exkursionsgebiet Basels. Revue Suisse de Zoologie $50,131-224$.

Gisin, H., 1960. Collembolenfauna Europas, Museum d'Histoire Naturelle, Genève, $312 \mathrm{pp}$..

Glantz, S.A., 1997. Primer of Biostatistics, McGraw-Hill, New York, $473 \mathrm{pp}$.

Greenacre, M.J., 1984. Theory and Applications of Correspondence Analysis, Academic Press, London, 364 pp..

Hågvar, S., 1982. Collembola in Norwegian coniferous forest soil. I. Relations to plant communities and soil fertility. Pedobiologia 24, 255-296.

Hågvar, S., Abrahamsen, G., 1984. Collembola in Norwegian coniferous forest soils. III. Relations to soil chemistry. Pedobiologia 27, $331-339$.

Hågvar, S., Abrahamsen, G., 1990. Microarthropoda and Enchytraeidae (Oligochaeta) in naturally lead-contaminated soil: a gradient study. Environmental Entomology 19, 1263-1277.

Halme, E., Niemelä, J., 1993. Carabid beetles in fragments of coniferous forest. Annales Zoologici Fennici 30, 17-30.

Hambuckers, A., Remacle, J., 1987. A six year nutrient budget in a coniferous watershed under atmospheric pollution. In: Mathy, P., (Ed.), Air Pollution and Ecosystems, Reidel, Dordrecht, pp. $814-816$

Hotelling, H., 1933. Analysis of a complex of statistical variables into principal components. Journal of Educational Psychology 24, 417-441.See also pages 498-520.

Jansson, P.E., 1987. Simulated soil temperature and moisture at a clearcutting in Central Sweden. Scandinavian Journal of Forest Research 2, 127-140.

Jordana, R., Arbea, J.I., Moraza, L., Montenegro, E., Mateo, M.D., Hernandez, M.A., Herrera, L., 1987. Effect of reafforestation by conifers in natural biotopes of middle and South Navarra (Northern Spain). Revue Suisse de Zoologie 94, 491-502.

Jordana, R., Arbea, J.I., Simón, C., Luciáñez, M.J., 1997. Fauna Iberica. VIII. Collembola Poduromorpha, Museo Nacional de Ciencias Naturales, and Consejo Superior de Investigaciones Científicas, Madrid, 807 pp..

Koerner, W., Dupouey, J.L., Dambrine, E., Benoît, M., 1997. Influence of past land use on the vegetation and soils of present day forest in the Vosges mountains, France. Journal of Ecology 85, 351-358.

Lebrun, P., 1976. Effets écologiques de la pollution atmosphérique sur les populations et communautés de microarthropodes corticoles (Acariens, Collemboles et Ptérygotes). Bulletin d'Écologie 7, $417-430$
Loranger, G., Bandyopadhyaya, I., Razaka, B., Ponge, J.F., 2001. Does soil acidity explain altitudinal sequences in collembolan communities? Soil Biology \& Biochemistry 33, 381-393.

Mateos, E., Selga, D., 1991. Efecto de los incendios forestales sobre las poblaciones de colémbolos edáficos en bosque mediterráneo. Revue d'Écologie et de Biologie du Sol 28, 19-30.

Mebes, K.H., Filser, J., 1997. A method for estimating the significance of surface dispersal for population fluctuations of Collembola in arable land. Pedobiologia 41, 115-122.

Odum, E.P., 1969. The strategy of ecosystem development. Science 164 $262-270$.

Ojala, R., Huhta, V., 2001. Dispersal of microarthropods in forest soil. Pedobiologia 45, 443-450.

Perrier, P., 1997. La forêt au Mont Beuvray: phytoscociologie. In: Buchsenschutz, O., Richard, H. (Eds.), L'Environnement du Mont Beuvray, Centre Archéologique Européen, Glux-en-Glenne, pp. 71-84.

Petersen, H., 2000. Collembola populations in an organic crop rotation: population dynamics and metabolism after conversion from clovergrass ley to spring barley. Pedobiologia 44, 502-515.

Plaisance, G., 1986. Évolution des paysages forestiers et arborés en Bourgogne et Franche-Comté de l'an mille à nos jours. Hommes et Terres du Nord, 190-195.

Ponge, J.F., 1980. Les biocénoses des Collemboles de la forêt de Sénart. In: Pesson, P., (Ed.), Actualités d'Écologie Forestière, Gauthier-Villars, Paris, pp. 151-176.

Ponge, J.F., 1993. Biocenoses of Collembola in atlantic temperate grasswoodland ecosystems. Pedobiologia 37, 223-244.

Ponge, J.F., Arpin, P., Sondag, F., Delecour, F., 1997. Soil fauna and site assessment in beech stands of the Belgian Ardennes. Canadian Journal of Forest Research 27, 2053-2064.

Ponge, J.F., Charnet, F., Allouard, J.M., 2000. Comment distinguer dysmoder et mor? L'exemple de la forêt domaniale de Perche-Trappe (Orne). Revue Forestière Française 52, 23-37.

Ponge, J.F., Chevalier, R., Loussot, P., 2002. Humus Index: an integrated tool for the assessment of forest floor and topsoil properties. Soil Science Society of America Journal 66, 1996-2001.

Prasse, I., 1985. Indications of structural changes in the communities of microarthropods of the soil in an agro-ecosystem after applying herbicides. Agriculture, Ecosystems and Environment 13, $205-215$.

Rameau, J.C., Mansion, D., Dumé, G., 1989. Flore Forestière Française. I. Plaines et Collines, IDF, Paris, 1785 pp.

Riepert, F., Kula, C., 1996. Development of laboratory methods for testing effects of chemicals and pesticides on Collembola and earthworms. Mitteilungen aus der Biologischen Bundesanstalt für Land- und Forstwirtschaft 320, 1-82

Rusek, J., 1989. Collembola and Protura in a meadow-forest ecotone. In: Dallai, R., (Ed.), Third Seminar on Apterygota, University of Siena, Siena, pp. 413-418.

Salmon, S., Ponge, J.F., 2001. Earthworm excreta attract soil springtails: laboratory experiments on Heteromurus nitidus (Collembola: Entomobryidae). Soil Biology \& Biochemistry 33, 1959-1969.

Shannon, C.E., 1948. A mathematical theory of communications. Bell System Technical Journal 27, 379-423.

Sterzyńska, M., 1990. Communities of Collembola in natural and transformed soils of the linden-oak-hornbeam sites of the Mazovian Lowland. Fragmenta Faunistica 34, 165-262.

Szeptycki, A., 1967. Fauna of the springtails (Collembola) of the Ojców National Park in Poland. Acta Zoologica Cracoviensia 12, 219-280.

Takeda, H., 1981. Effects of shifting cultivation on the soil meso-fauna with special reference to collembolan populations in the North-East Thailand. Memoirs of the College of Agriculture, Kyoto University 118, 45-60. 
Takeda, H., 1987. Dynamics and maintenance of collembolan community structure in a forest soil system. Researches on Population Ecology 29, 291-346.

Tamm, C.O., Hallbäcken, L., 1988. Changes in soil acidity in two forest areas with different acid deposition: 1920s to 1980s. Ambio 17, 56-61.

Ter Braak, C.J.F., 1987. The analysis of vegetation-environment relationships by canonical correspondence analysis. Vegetatio 69, 69-77.

Tilman, D., 1999. Diversity and production in European grasslands. Science 286, 1099-1100.

Topoliantz, S., Ponge, J.F., Viaux, P., 2000. Earthworm and enchytraeid activity under different arable farming systems, as exemplified by biogenic structures. Plant and Soil 225, 39-51.
Usher, M.B., 1970. Seasonal and vertical distribution of a population of soil arthropods: Collembola. Pedobiologia 10, 224-236.

Van Amelsvoort, P.A.M., Van Dongen, M., Van der Werff, P.A., 1988. The impact of Collembola on humification and mineralization of soil organic matter. Pedobiologia 31, 103-111.

Vilkamaa, P., Huhta, V., 1986. Effect of fertilization and $\mathrm{pH}$ on communities of Collembola in pine forest soil. Annales Zoologici Fennici 23, 167-174.

Winkler, H., Kamplicher, C., 2000. Local and regional species richness in communities of surface-dwelling grassland Collembola: indication of species saturation. Ecography 23, 385-392.

Zimdars, B., Dunger, W., 1994. Synopses on palaearctic Collembola. I. Tullbergiinae. Abhandlungen und Berichte des Naturkundemuseums Görlitz 68, 1-71. 